\title{
Aleksandra Sulikowska, Ciała, groby i ikony. Kult świętych $w$ ruskiej tradycji literackiej $i$ ikonograficznej, Wydawnictwo Neriton, Warszawa 2013, ss. $442+64$ il.
}

Dr Aleksandra Sulikowska jest znaną postacią w gronie polskich badaczy dziejów ikonografii wschodniochrześcijańskiej i historii sztuki ruskiej. Jej prace, poświęcone głównie dziejom ikonografii wschodniej, pojawiały się wielokrotnie jako ważne odsyłacze w publikacjach naukowych. Opublikowany dorobek naukowy Aleksandry Sulikowskiej stanowi znaczący wkład w badaniach nad historią sztuki i ikonografii ruskiej, bizantyjskiej, gruzińskiej i bałkańskiej.

W dotychczasowym dorobku naukowym Aleksandry Sulikowskiej najważniejszym osiągnięciem była rozprawa doktorska Spory o ikony na Rusi w XV i XVI w. Praca ta, wydana w 2007 roku, stanowi ważny wkład w poznanie dziejów malarstwa ruskiego i malarstwa ikonowego w XV i XVI wieku oraz jego percepcji w sztuce cerkiewnej w następnych stuleciach. Sulikowska publikowała też w renomowanych periodykach naukowych, jak: „Mówią Wieki”, „Series Byzantina”, „Pro Georgia. Journal of Kartvelological Studies”, „Ikonotheka” czy „Krakowsko-Wileńskie Studia Slawistyczne”.

Książka Aleksandry Sulikowskiej Ciała, groby i ikony. Kult świętych w ruskiej tradycji literackiej $i$ ikonograficznej, została podzielona na dwie części: pierwsza (złożona z czterech rozdziałów) poświęcona jest roli relikwii świętych w Kościele wschodnim, a druga (złożona z trzech rozdziałów) analizuje ikony jako obiekt kultu, omawia publiczny aspekt oddawania czci świętym relikwiom i ikonom. Rozprawa składa się ze wstępu, siedmiu obszernych rozdziałów, zakończenia, abstraktu w języku angielskim (brak w języku rosyjskim), bibliografii, indeksu osób, indeksu rzeczowego, spisu ilustracji i 64 kolorowych ilustracji.

Autorka postawiała sobie za cel ukazanie kultu świętych w tradycji prawosławnej przez pryzmat funkcjonowania w niej ikon i relikwii. Autorka wykorzystuje obszerną literaturę o różnej wartości poznawczej i o zróżnicowanej przydat- 
ności ${ }^{1}$ Rozdział pierwszy pierwszej części książki poświęcony został wyobrażeniom świętości w ruskiej tradycji literackiej i ikonograficznej oraz najpopularniejszym świętym i ikonom na Rusi. Ikony, po likwidacji w drugiej połowie IX wieku obrazoburstwa, stworzyły nowy model tożsamości religijnej, gdzie święci i ikony zajmowali wyjątkowe miejsce. A. Sulikowska rozpoczyna swoją analizę od ukazania popularnych świętych z terenów południowo-wschodniej Polski i zachodniej Ukrainy (bez uwzględnienia obszarów białoruskich) w malarstwie ikonograficznym i na tej podstawie wnioskuje o ich szczególnej czci wśród wiernych. Zgadzam się z opinią autorki książki, że znajomość XV-XVI-wiecznego malarstwa zachodnioruskiego jest fragmentaryczna. Kult świętych wyobrażonych na ikonach nie jest jedynym źródłem do ukazania ich popularności. Zwłaszcza opinii takiej nie należy formułować $\mathrm{w}$ odniesieniu do tych zachowanych fragmentów, które stanowiły wyposażenie świątyń. Bardziej wiarygodne są pod tym względem są wizytacje i opisy cerkwi lub ich wezwania. Wiadomo, że bardzo popularnymi na ziemiach ruskich byli święci, którym oddawano wielką cześć w Bizancjum: święci Ojcowie Kościoła Bazyli Wielki, Jan Złotousty i Grzegorz Teolog; św. Jerzy, św. Michał Archanioł (rycerze święci), św. Zofia (wezwanie soboru w Konstantynopolu), św. Mikołaj (patron handlarzy i podróżników), etc. Tymczasem według badań dr Aleksandry Sulikowskiej popularnymi w ikonografii są święci bałkańscy i bizantyjscy, a nie ruscy z pierwszych czterech stuleci po chrystianizacji. Ten ważny problem badawczy powinien być wyjaśniony, albowiem dotyka on tożsamości religijnej i kulturowej mieszkańców dawnej Rusi Kijowskiej. Podstawione na s. 29 pytanie, dlaczego te a nie inne postacie świętych z kręgu bizantyjskiego (dodałbym i bałkańskiego) rozwinęły się na ziemiach ruskich państwa polsko-litewskiego pozostało bez odpowiedzi.

Autorka książki trafnie zwraca uwagę na rolę Konstantynopola dla prawosławnej Słowiańszczyzny. Kulty świętych, które przybyli z tamtego obszaru, to nie tylko efekt kierunku procesów chrystianizacyjnych, ale i stałych kontaktów

1 Pomimo zamieszczonej ogromnej bibliografii należałoby ją uzupełnić o dość istotne dla tej problematyki opracowania, takie jak: E. Levin, Sex and Society in the World of the Orthodox Slavs, 900-1700, London 1989; A. Różycka-Bryzek, Bizantyjskie malarstwo jako wykładnia prawd wiary. Recepcja na Rusi - drogi przenikania do Polski, [w:] Chrześcijańskie dziedzictwo bizantyjsko-stowiańskie, pod red. A. Kubiś i A. Ruseckiego, Lublin 1994; A. Mironowicz, Kultura prawosławna w dawnej Rzeczypospolitej, [w:] Rzeczpospolita wielu wyznań, pod red. A. Kaźmierczyka, A. Link-Lenczowskiego, M. Markiewicza i K. Matwijowskiego, Kraków 2004; Idem, Księga cudów przed ikonq Matki Bożej w Starym Korninie dokonanych, Białystok 1997; Idem, Księga cudów przed ikonq Matki Bożej Waśkowskiej dokonanych, Białystok 2012; E. Chojecka, Sztuka średniowiecznej Rusi Kijowskiej i jej zwiazki z Polskq w XI-XV w., [w:] Ukraina. Teraźniejszość i przeszłość, pod red M. Karasia i A. Podrazy, „Zeszyty Naukowe Uniwersytetu Jagiellońskiego. Prace Historyczne”, R. CCXLVII, z. 32, Kraków 1970; A. I. Rogow, Kulturnyje swiazi Rusi i Polszy w XIV - naczale XV w., „Wiestnik Moskowskogo Uniwiersitieta”, sierija IX, Istorija, 1972, z. 4; G. Łużnickij, Słownik Czudotwornich Bohorodicznych ikon Ukraijny, „In trepido Pastori”, Rim 1984; W. Niżyński, Teologia kultu maryjnego w katolicyzmie, [w:] Kult Maryjny w Kościele rzymskokatolickim w Polsce $i$ w Rosyjskim Kościele prawosławnym w Rosji, Warszawa - Moskwa 1989. 
w późniejszych stuleciach. Proces ten nasilił się po upadku Konstantynopola, kiedy to wielu duchownych i świeckich przybyło znad Bosforu w granice Wielkiego Księstwa Litewskiego. Kult świętych serbskich i bułgarskich to niewątpliwie zasługa obecności wielu duchownych w tamtym kręgu religijnym, zwłaszcza odnosi się to do metropolitów kijowskich i litewskich Cypriana (1389-1406), Grzegorza Camblaka (1415-1419) i Grzegorza Bułgara (1458-1473).

W tym rozdziale niepotrzebnie stosuje się pojęcie ,ikony chramowe” (s. 25) w odniesieniu do ikon stanowiących wyposażenie świątyń. Właściwszy byłby termin , ikony cerkiewne”. Do grona świętych rycerzy, a nie „wojowników” (Jerzego, Teodora), dodałbym Michała Archanioła. Należy też zweryfikować stwierdzenie dr Aleksandry Sulikowskiej, że ,istota uznania świętego polegała na wyznaczeniu dnia (lub też dni) w którym czczono jego pamięć; pod tą datą jego imię pojawiało się odtąd w kalendarzach kościelnych" (s. 56). Trzeba zaznaczyć, że nieprzypadkowo wyznaczano datę liturgicznej pamięci święta kanonizowanej osoby. Zazwyczaj określał ją dzień jej śmierci, zaś dodatkową datę oddawania czci ustanawiano na dzień przeniesienia relikwii świętej osoby do nowego miejsca.

Z uznaniem należy ocenić wysiłki badawcze dr Aleksandry Sulikowskiej przy omawianiu dwóch kolejnych rozdziałów. Zawarta w nich bogata faktografia wnosi wiele elementów poznawczych. Autorka podkreśliła rolę męczenników w kształtowaniu obrazu kultu świętych i pojmowania miejsca człowieka w świecie wartości chrześcijańskich. W tym rozdziale powinien być w szerszym zakresie wyjaśniony kult nowych świętych na ziemi ruskiej. Kult pierwszych ruskich świętych był wyrazem dojrzałości chrześcijaństwa na terenie Rusi Kijowskiej. Pierwszymi kanonizowanymi świętymi byli kniaziowie Borys i Gleb. Borys i Gleb zostali uznani za świętych nie jako męczennicy, ale jako „strastotierpcy", tzn. cierpiący męki. W ten sposób powstał nowy typ świętości, znany szczególnie na Rusi Kijowskiej. Mianem „strastotierpców” nazwano w późniejszym czasie następujących książąt: kijowskiego Jerzego Olgowicza (+1147 r.), Andrzeja Bogolubskiego (+1174) r., muromskiego Konstantyna (+1205 r.), czernihowskiego Michała Wsiewołodowicza (+1246 r.) i wielu innych.

Narody szczególną czcią otaczają „równoapostołów”, a więc tych świętych, dzięki którym wiara chrześcijańska do nich trafiła. Tytuł „równy apostołom” (gr. isoapostolos) $\mathrm{w}$ tradycji bizantyjskiej przypisuje się zwykle pierwszym misjonarzom danego kraju, np. św. Ninie w Gruzji czy św. św. Cyrylowi i Metodemu w Słowacji. W wypadku ziem ruskich mianem tym określano księżnę Olgę i księcia Włodzimierza. Olga i Włodzimierz zostali obdarzeni tym tytułem nie wskutek własnej świętości, ale ze względu na ich rolę w chrystianizacji narodu.

Kolejną grupą wśród pierwszych świętych ruskich są ,podwiżniki”. Określenie to dotyczy osób duchownych i świeckich podejmujących heroiczny wysiłek duchowo-ascetyczny. Postawa „podwiżników” dotyczy umartwień, modlitw, walki z pokusami i złem. Miano ,prepodobnych” nadawano mnichom, którzy 
przez ascetyczny wysiłek osiągnęli świętość i upodobnili się do Chrystusa. W stosunku do żyjących zakonników tytuł ten oznaczał mnicha czcigodnego. Określenia ,prepodobnyj” i ,podwiżnik” odnoszono do Antoniego i Teodozego Pieczerskich oraz wielu innych świętych mnichów. Święci hierarchowie (biskupi) stanowią kolejną grupę osób kanonizowanych. Hierarchowie ci w tradycji cerkiewnej noszą miano „światitieli” w związku z ich kapłańską i pasterską posługą. Biskupi nie otrzymywali lauru świętości tylko za akty heroicznej ascezy, ale głównie za posługę Kościołowi.

Osobną grupę świętych stanowią „błagowierni” książęta. Mianem tym, oprócz Włodzimierza i Olgi, określano panujących, którzy przyczynili się do rozwoju chrześcijaństwa i prowadzili życie zgodne z nauką Kościoła. Do tego grona należy książę smoleński Rościsław (1126-1168). Popularność kultu św. książąt wynikała $\mathrm{z}$ ich roli w rozwoju i obronie struktur kościelnych (Andrzej Bogolubski) oraz z tego, że stanowili wzór do naśladowania w okresie najazdu mongolskiego. W drugiej połowie XIII i w ciągu XIV w. kulty „równych apostołom”, „strastotierpców”, ,prepodobnych”, ,podwiżników” i „światitieli” zostały zastąpione kultem „męczennicy za wiarę”. Do grona męczenników należą: męczennik Jelisiej Ławryszowski (XIII/XIV) oraz święci wileńscy Antoni, Jan i Eustachy (zm. 1347 r.), którzy przyczynili się do rozwoju chrześcijaństwa na Litwie.

W tym kontekście za szczególnie wartościowe należy uznać fragmenty rozdziału ukazujące popularność poszczególnych kategorii świętych na ziemiach ruskich i Bizancjum, „funkcję” świętych i ich patronat nad różnymi grupami społecznymi. Rola świętych sprowadza się nie tylko do roli pośrednika pomiędzy wierzącym a Bogiem i „drogowskazu moralnego” - jak podkreśla A. Sulikowska - ale też do roli opiekuna i obrońcy. Każdy wierzący w tradycji wschodniej ma swego ,anioła stróża”, którego otrzymuje wraz z imieniem podczas chrztu. Otrzymane imię jest najczęściej nadawane ku czci tego świętego, którego wierzący wybrał na swego opiekuna i modlitewnika przed Bogiem. Ażeby zrozumieć rolę świętych, należałoby sięgnąć, w wielu fragmentach książki, do opracowań poświęconych teologii prawosławnej, a nie do utworów religijno-literackich, nie zawsze oddających istotę zjawiska. Uwaga ta dotyczy między innymi omawiania „wyobrażenia obecności świętego w raju”. Literatura hagiograficzna i prezentacja świętego na ikonie zawsze były zgodne z nauką Cerkwi.

W drugim rozdziale części pierwszej książki autorka dokonuje analizy wyobrażeń cielesności w ikonie oraz próbuje dokonać rekonstrukcji znaczenia cielesności w kulturze prawosławnej na podstawie źródeł literackich. Zgadzam się z opinią A. Sulikowskiej, że „cielesność jest jednym z najważniejszych pojęć literatury wschodniochrześcijańskiej”. W słowiańskiej i bizantyjskiej literaturze prawosławnej słabość ludzkiego ciała wynikała ze słabości ducha. Autorka słusznie przytacza w tym miejscu pisma Ojców Kościoła, którzy zwracali uwagę na dwoistość człowieka, jego podział na duszę i ciało. Ciało powstało z materii, w którą Bóg tchnął duszę. Związek ciała z ziemią w świetle literatury cerkiew- 
nosłowiańskiej jest przyczyną problemów człowieka. Dusza jest więziona w ciele i dopiero śmierć ciała czyni ją wolną. Traktowanie ciała jako miejsce grzechu i namiętności nie jest powszechne w literaturze. I dobrze, że A. Sulikowska przywołała tu słowa Grzegorza Palamasa. Według tego wybitnego prawosławnego teologa ciało, poddane kontroli umysłu, powinno uczestniczyć w modlitwie.

Następnie autorka książki podnosi wątek prezentacji w ikonografii prawosławnej przedstawień stworzenia i upadku człowieka. A. Sulikowska ukazuje nam znane i nieznane prezentacje Adama i Ewy, a zwłaszcza moment ich wygnania z Raju. Nie zawsze nagość obydwojga postaci jest przykrywana liśćmi. Na ikonie „Symbol wiary” z połowy XVII wieku Adam i Ewa ukazani zostali niemal w pełnej nagości (V. G. Brjusova, Russkaja źivopiś 17 veka, Moskwa 1984, nr 115; E. Levin, Sex and Society in the World of the Orthodox Slavs, 900-1700, London 1989, s. 47). Nie wiem, czy A. Sulikowska w interpretacji sceny wygnania naszych prarodziców nie posunęła się zbyt daleko. Wygnanie z Raju miało, według badaczki, oznaczać utratę nieśmiertelności ciała i skazanie go na śmierć. Teologia prawosławna daje jednak nadzieję: ciało jest śmiertelne, ale dusza nie. Ciało jest połączone duszą, jest jej zewnętrzną powłoką. Nieśmiertelność duszy i jej Boskie pochodzenie daje człowiekowi szansę na życie wieczne. W akcie zmartwychwstania dusza ponownie wciela się w ciało. $Z$ tego powodu w ikonografii prawosławnej podkreśla się świat przebóstwiony. Postacie świętych na ikonach są symbolem nieśmiertelności i triumfu świata duszy, nadziei na życie wieczne.

Za niezwykle cenny należy uznać fragment książki poświęcony przemienieniu ciała i ukazaniu postaci świętych na ikonach. Przykłady ze scen żywota Marii Egipskiej, Paraskiewy Tyrnowskiej, Symeona Stylity, Antoniego Wielkiego, Jana Rylskiego, Grzegorza z Nyssy podkreślają ich cierpienie, poświęcenie Bogu i pogardę dla życia doczesnego. Autorka książki wykorzystała w tym miejscu dotychczasowe ustalenia badaczy i je usystematyzowała. Podnosząc piękno ciała świętych, słusznie zwraca uwagę, że to Boskie piękno (np. Jerzego z Kratowa czy św. Paraskiewy) dla samych męczenników nie miało istotnego znaczenia. W literaturze bizantyjskiej spotykamy wielu świętych, którzy nawet świadomie oszpecali ciało, ażeby nie było ono obiektem czyjegokolwiek pożądania. Ukazywanie fragmentów odsłoniętego ciała na ikonach należy do rzadkości i zaprezentowane było przy okazji opisania męczeństwa świętych (odsłonięte piersi czy plecy). A. Sulikowska pomija - nie wiadomo, dlaczego - sceny Sądu Ostatecznego czy znane freski z monasteru w Rostowie ukazujące „Męczenie prostytutek" (V. G. Brjusova, Russkaja źivopiś 17 veka, Moskwa 1984, nr 123) $\mathrm{z}$ obnażonymi postaciami.

Kolejny rozdział części pierwszej stanowi omówienie roli świętych relikwii i ich wizerunków w tradycji wschodniochrześcjańskiej. W Cerkwi prawosławnej relikwie są niezbędne do konsekracji świątyni. Kult relikwii był powszechny w Bizancjum i wśród narodów słowiańskich. Nie mam zastrzeżeń do prezentacji istoty relikwii i ich roli w życiu chrześcijan. Na podstawie reprezentatywnej lite- 
ratury A. Sulikowska wskazuje na trzy elementy, które są istotne przy ustalaniu dni szczególnego oddawania czci relikwiom świętych. Mowa tu o odnalezieniu, ewentualnym przeniesieniu i złożeniu w miejscu ich obecnego przechowywania. Istotną kwestią - nierozerwalną ze szczątkami ciał osób świętych - jest fakt ich kanonizacji. Bez ogłoszenia przez Cerkiew osoby jako świętej nie mogą być ciała zmarłych traktowane jako relikwie. A. Sulikowska właściwie interpretuje znaczenie odnalezionych relikwii w życiu chrześcijan, które stają się dla nich obiektem kultu, namacalnym dowodem istnienia świętych. Niejednokrotnie w obawie przed ich zatraceniem wierni chowali relikwie, które zapomniane - same dawały znać o swym istnieniu. Do licznych, podanych w pracy, wypadków ich odnalezienia (np. relikwii św. Klemensa, papieża - przez świętych Cyryla i Metodego) przywołałbym również odnalezienie głowy św. Pantelejmona w monasterze na wyspie Andros. Ukryta w czasie inwazji tureckiej, dopiero po odzyskaniu niepodległości przez Grecję, dzięki wonnościom wydobywającym się spod posadzki świątyni ponownie dała znać wspólnocie zakonnej o swym istnieniu.

A. Sulikowska właściwie interpretuje zjawisko „mirotoczenija”, czyli wydobywania się oleju wonnego $\mathrm{z}$ relikwii świętych lub ikon. Zjawisko to, powszechnie znane choćby na przykładzie św. Mikołaja z Miry Licyjskiej czy św. Dymitra z Salonik, występowało także przy „moszczach” wielu świętych wschodniosłowiańskich. W tradycji wschodniej miły zapach przypisuje się świętym relikwiom. Szkoda, że autorka pracy nie spróbowała odnaleźć w literaturze i teologii prawosławnej wytłumaczenie tego zjawiska. „Mirotoczenie” świętych, a zwłaszcza ikon, nie tylko jest postrzegane jako dar i łaska okazywana przez Boga wiernym. Często zwiastuje nieszczęścia. Masowe „płakanie ikon” wielokrotnie występowało na terenie ziem ruskich w przededniu katastrof $\mathrm{i}$ wojen. Tak było w ostatnich latach przed wojną domową w Syrii czy Egipcie, gdzie „mirotoczenije” ikon uznaje się jako zwiastun ciężkich czasów, które nastały dla miejscowych chrześcijan.

W tradycji wschodniej najważniejszą wartością było posiadanie przez wspólnotę ikon i relikwii świętych. Namacalna obecność świętego w postaci relikwii czy jego ikony wzmacniała wiarę wśród wierzących i gwarantowała pomoc. Kult ikon był bardziej powszechny aniżeli relikwii. Obecność ikony nie jest oznaczeniem miejsca świętego (s. 177), ale potwierdzeniem jego obecności. Święty w postaci licznych kopii ikon stawał się wszechobecny wśród wiernych.

Kolejny rozdział części pierwszej został poświęcony cudom dokonywanym przy relikwiach świętych i ich ikonach. Nie mogę się zgodzić z autorką książki w kwestii pojmowania cudownych zdarzeń przy ikonach i relikwiach świętych jako kontynuacji magii pogańskiej. Owszem, magia była wszechobecna nawet wśród chrześcijańskich mieszkańców Bizancjum i Wschodnich Słowian, ale nadprzyrodzone cuda to efekt objawień i głębokiej wiary w Boga. Cud dokonany przed relikwiami świętego albo przed ikoną w literaturze ruskiej jest postrzegany jako znak i dowód mocy Boga lub świętych. Szkoda, że dr A. Sulikow- 
ska nie przywołała jakże trafnych słów archimandryty Sylwestra Kossowa, który w Paterikonie, albo żywoty świętych Ojców Pieczerkich obszyrnie stowieńskim językiem przez świętego Nestora zakonnika i latopisca ruskiego przedtym napisany, teraz zaś z greckich, tacińskich, słowiańskich i polskich pisarzów objaśniony $i$ krócej podany przez wielebnego w Bogu ojca Sylwestra Kossowa, episkopa mścisławskiego, orszańskiego i mohilewskiego napisał, że praca ta powstała celem pokazania nieomylnej świq̨tobliwości świętych ojców peczerskich, w ciele niespróchniałych, od kilkuset lat leżących $w$ pieczerach kijowskich, a na dowód cudów prawdziwych, które przy ich reliquiach działy i dzieją. I dalej: Przechadzając się, [...] po pieczerach kijowskich, grobach ojców świętych, swiętym ich $i$ nieskazitelnym cudując sie ciałom, nie raz rzewno zaptakałem, uważajac to, ze nieszczęsne $i$ zawisłe wieki tak godnie dotychczas nie objawiły światu wybranych Bożych, jako sam Pan Bóg objawit. Podane przez autorkę książki przykłady cudów opisane w literaturze ruskiej odsłaniają moc świętych. Postulatem badawczym pozostaje wykonanie katalogu relikwii świętych, które w XV i XVI wieku oddziaływały na życie religijne wiernych. Problem, który został pominięty w pracy, to czas trwania kultu relikwii i ich zasięg. Obok powszechnie znanych cudownych relikwii i ikon były również te o znaczeniu lokalnym. Nieliczne księgi cudów dają podstawę do określenia zasięgu oddziaływania cudownych relikwii czy ikon.

Nie mam istotnych uwag do fragmentu pracy poświęconego świętym uzdrowicielom: św. św. Kosmie i Damianowi, św. Mikołajowi i innym. Nie wiadomo, dlaczego autorka książki pominęła bardzo popularnych na ziemiach ruskich innych uzdrowicieli: św. Pantelejmona i św. Jerzego. Ten ostatni był traktowany nie tylko jako obrońca wiernych, ale i opiekun chorych. W modlitwie do świętego znajdują się takie określenia: ,jako uwięzionych wyzwoliciel, pozostających w niemocy lekarz". Osobne miejsca uzdrowień znajdowały się przy cudownych źródełkach. Sama woda, jako źródło uzdrowienia, ma jedynie symboliczny charakter. Uzdrowienie przy cudownym źródle nie wynika z samego istnienia źródła, ale z faktu modlitwy przy nim świętego (np. Jana Rylskiego) lub miejsca jego objawienia $^{2}$. W części drugiej A. Sulikowska w sposób bardziej profesjonalny podejmuje problem przedstawienia ikonograficznego życia świętych, konfrontując je z piśmiennictwem hagiograficznym. W pierwszym rozdziale tej części ukazane zostały cykle hagiograficzne na ikonach świętych. Treści tych cykli obejmują ikonograficzne przedstawienie spisanych żywotów świętych, cudów, przeniesienia relikwii etc. Autorka pracy, jako wybitna specjalistka ruskiej sztuki

2 Odnośnie podlaskich „krynoczek” - miejsca te powstawały po objawieniu się nad źródełkami postaci Matki Bożej lub jej ikony i stawały się lokalnymi ośrodkami kultowymi. (A. Mironowicz, Prawosławny ośrodek kultowy w Piatience, [w:] Kościót - Społeczeństwo - Kultura. Prace ofiarowane Profesorowi Wiesławowi Müllerowi z okazji pięćdziesięciolecia pracy naukowej i dydaktycznej, pod red. J. Droba, Lublin 2004, s. 211-220; G. Sosna, Swięte miejsca i cudowne ikony. Prawosławne sanktuaria na Białostocczyźnie, Białystok 2001). 
ikonograficznej, umiejętnie opisuje rozmieszczenie cykli hagiograficznych wokół centralnej postaci świętej. Wyłapanie różnic kompozycyjnych ikon hagiograficznych w tradycji bizantyjskiej, ruskiej, mołdawskiej i bałkańskiej to wielkie osiągnięcie dr A. Sulikowskiej. Zgadzam się też, że w każdej ze scen cyklu hagiograficznego postać świętego znajdowała się w centrum kompozycji. Osobiście do szczegółowej analizy tego zjawiska poleciłbym przykład XVI-wiecznej ikony św. Mikołaja w cerkwi w Kleszczelach. Ikona ta jest wprost modelowym przykładem obecności na wschodnich obszarach Polski bizantyjskiej ikony hagiograficznej o wielkich rozmiarach.

$\mathrm{Z}$ pełnym uznaniem odnoszę się do ustaleń A. Sulikowskiej, kiedy omawia - i dokumentuje ikonograficznie - poszczególne kompozycje cyklu hagiograficznego: wyobrażenia narodzin świętego, sceny z jego życia, śmierci, cudów z nim związanych. Za szczególnie ważne podkreślenia uważam uwagi autorki książki o ikonograficznych wyobrażeniach śmierci naturalnej i męczeńskiej oraz zaśnięcia. Autorka koncentruje się na ikonach przedstawiających Zaśnięcie NMP zapominając, że w podobnej kompozycji była przedstawiana św. Anna. Brak tego omówienia i ikonograficznego przedstawienia nie podważa postawionych $\mathrm{w}$ tym rozdziale tez.

$\mathrm{Z}$ wielkim uznaniem odnoszę się do literackiego i ikonograficznego ukazania losów duszy zmarłego: od momentu opuszczenia przez nią ciała do powrotu w dniu zmartwychwstania. Autorka pracy wykazała się tu dużą umiejętnością połączenia TREŚCI tekstów hagiograficznych i teologicznych z przedstawieniami ikonograficznymi. Śmierć - nazywana w odniesieniu do pobożnych ludzi ,,prestawlenie", czyli przeniesienie z życia doczesnego do wieczności - nie oznacza $\mathrm{w}$ teologii prawosławnej umierania, a zmianę miejsca. $\mathrm{W}$ takim rozumieniu śmierć nie jest tragedią, a czasowym rozstaniem duszy i ciała. Takie przesłanie dr A. Sulikowska wydobywa w ikonie „Uspienia”, czyli Zaśnięcia NMP. Dusza, pozbawiona płci, owinięta białą tkaniną, czeka na zmartwychwstanie (święci, pobożni) lub Sąd Ostateczny (grzesznicy).

W rozdziale drugim tej części A. Sulikowska na ikonograficznych prezentacjach opisuje pochówek ciała. W tradycji bizantyjskiej i żydowskiej pogrzeb jest niezbędnym rytuałem związanym z zakończeniem ziemskiego losu człowieka. Jedynie dla ascetów ruskich, takich jak Nil Sorski, nieposiadanie grobu było związane z wyrzeczeniem się doczesności. Autorka umiejętnie omawia opisy pogrzebów, zalecenia w tym względzie metropolity Piotra Mohyły i ikonograficzne prezentacje pochówku osób świętych. Sam pochówek nazywany jest na ikonach jako „złożenie do grobu”, „złożenie relikwii” czy „zaśnięcie w Bogu”. Za szczególnie cenny uważam fragment pracy omawiający przeniesienie relikwii, w tym ukazanie wielu wersji przeniesienia ciała św. Mikołaja z Mirry do Bari. Oczywiście, można by podać inne powody zmiany lokalizacji relikwii świętych np. z powodu najazdów czy klęsk elementarnych (trzęsienia ziemi), ale głównym powodem przeniesienia w podanych przez autorkę książki przykładach była 
decyzja hierarchów kościelnych lub panujących. Dr A. Sulikowska sama doskonale tę tezę potwierdza, wskazując na osoby towarzyszące przeniesieniu relikwii i nadanie im publicznego charakteru. Podane przedstawienia na ikonach św. Sawy Serbskiego, św. Mikołaja czy świętych Borysa i Gleba są dobrym przykładem potwierdzającym tę tezę.

Autorka książki poprzez przedstawienia ikonograficzne potwierdza, że celem życia ludzkiego jest zmartwychwstanie, a pobyt na ziemi jest podporządkowany temu dążeniu. Sceny z życia świętych od narodzin do pogrzebu ukazywały jedynie drogę do transcendentalnej przyszłości po śmierci.

W rozdziale tym, przy omawianiu patronów (niepotrzebnie) pominięto apostoła Andrzeja jako patrona ziem ruskich. Już kronikarz Nestor pragnął nadać Cerkwi ruskiej apostolski charakter. W mniemaniu kronikarza, Kościół prawdziwy to Kościół założony przez apostoła. Wprowadzenie rzekomego pobytu apostoła Andrzeja na ziemiach ruskich miało podnieść prestiż nowej prowincji cerkiewnej. Jeżeli chodzi o księcia Włodzimierza to najlepiej jego rolę określił metropolita Iłarion w Pochwale księcia Włodzimierza. W rozumieniu Iłariona, książę Włodzimierz przez ewangelizację swego państwa w świecie chrześcijańskim może być uznawany za równego apostołom. Gdy do tego dodamy osiągnięte przy pomocy Cerkwi liczne sukcesy w rozbudowie struktur państwowych, jego postać jako władcy chrześcijańskiego zasługuje na szczególne wyróżnienie. Hagiografowie porównywali wielokrotnie Olgę i Włodzimierza do bizantyjskich świętych - cesarzowej Heleny i cesarza Konstantyna Wielkiego. Nawrócenie obojga książąt było darem Bożym dla całego narodu ruskiego. Według Iłariona zasługi księcia Włodzimierza w rozwoju chrześcijaństwa są takie same, jak działania ewangelizacyjne cesarza Konstantyna. „On (Włodzimierz) jest nowy Konstantyn wielkiego Rzymu, który ochrzcił się sam i ludzi swych ochrzcił”. W świadomości zbiorowej Rusinów idea równości Rusi z Bizancjum została podkreślona poprzez wybudowanie w głównych centrach państwa Rusi Kijowskiej (Kijowie, Połocku, Nowogrodzie Wielkim) cerkwi sobornych św. Zofii (Mądrości Bożej), nawiązujących do świątyni pod tym samym wezwaniem w Konstantynopolu.

W zakończeniu książki A. Sulikowska podsumowała swoje ustalenia i wskazała na rolę kultu relikwii i cudownych ikon w kształtowaniu wyobraźni zbiorowej wiernych. Autorka pracy podała też wiele przykładów kontynuacji kultu w czasach nam współczesnych w tradycji wschodnio i zachodniochrześcijańskiej na terenie Polski. Wypada zgodzić się z konkluzją autorki książki, że ikony i relikwie są symbolami świata niewidzialnego. Świat ten, tak jak wierzącym w XV i XVI stuleciu, również dziś staje się dostępny ludzkim zmysłom poprzez obecność ikon i relikwii świętych.

Pomimo wyrażonych wyżej uwag krytycznych moja opinia o książce Aleksandry Sulikowskiej jest w pełni pozytywna. Jej główną wartością jest przedstawienie wyobrażeń wiernych o świętości i cielesności człowieka oraz relacji zachodzących pomiędzy światem żywych i zmarłych. Drugim dominującym 
wątkiem książki jest wieloaspektowe spojrzenie na świętych w tradycji wschodniochrześcjańskiej oraz ukazanie publicznego aspektu oddawania czci ikonom i relikwiom. $\mathrm{Z}$ tego zamierzenia autorka pracy wywiązała się doskonale, a także z powodzeniem zrealizowała postawiony sobie cel wypełnienia luki w badaniach nad tą tematyką.

Należy zwrócić uwagę na połączenie w recenzowanej książce wielu elementów o charakterze historycznym, teologicznym, literackim i kulturowym. A. Sulikowska zmuszona była wydobyć w pismach hagiograficznych i w ikonografii hagiograficznej obraz świętych i ich wyobrażenia przez ówczesne społeczeństwo. Ażeby ten cel zrealizować dr A. Sulikowska zmuszona była sięgnąć do kwestii teologicznych, dogmatycznych, literackich i historycznych, dogłębnie zrozumieć uwarunkowania kulturowe towarzyszące powstawaniu omawianych prac. Wieloaspektowy ogląd dzieł pozwolił autorce książki ukazać istotę kultu ikon i relikwii świętych. Jestem przekonany, że recenzowana praca stanie się ważnym wkładem w poznanie dziejów myśli religijnej i artystycznej mieszkańców ziem ruskich dawnej Rzeczypospolitej.

Antoni Mironowicz Wydział Historyczno-Socjologiczny Uniwersytet w Białymstoku 